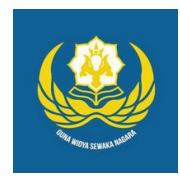

Jurnal Analogi Hukum

Journal Homepage: https://ejournal.warmadewa.ac.id/index.php/analogihukum

\title{
Tanggung Jawab Penerbit Cek Sebagai Upaya Perlindungan Hukum terhadap Pemegang Cek Kosong
}

\author{
I Gusti Made Raamdhana Prandiva Smapta*, Ni Luh Made Mahendrawati dan I Ketut Sukadana
}

Fakultas Hukum, Universitas Warmadewa, Denpasar, Bali-Indonesia

*prandiva.smapta@gmail.com

How To Cite:

Smapta, I. G. M. R. P., Mahendrawati, N. L. M., \& ., Sukadana, I. K. (2020). Tanggung Jawab Penerbit Cek Sebagai Upaya Perlindungan Hukum terhadap Pemegang Cek Kosong. Analogi Hukum. 2(1). 47-52. Doi: http://dx.doi.org/10.22225/.2.1.1611.47-52

\begin{abstract}
In society today checks as securities are commonly used in trade transactions as a practical means of payment, can be transferred from one hand to another, so as to support the smooth running of trade. Checks as unconditional orders from account holders or current accounts to banks to pay a certain amount of money. However, the problem is when submitted to the bank it turns out that the customer's funds at the bank are insufficient to pay the check letter in question or often referred to as a blank check. In this research the author raises the problem of how the responsibility of the issuer checks is related to payment by using a blank check and how is the legal protection of the recipient of the check when receiving payment with a blank check. The type of research used in this paper is normative legal research. In the KUHD, a blank check puller or someone who is at the cost of the check is withdrawn, is obliged to try so that the funds required for payment on the day of submission are interested, even if the check is determined to be paid by a third party, without reducing the towing obligations in accordance with article. Legal protection against recipients of blank checks is a legal guarantee in the form of recourse rights in the event that there is no payment of new recourse rights will arise if the holder of the check certificate does not receive payment from being caught after being asked to pay within 70 days of the issuance date.
\end{abstract}

Keywords: Blank Check, Legal Protection, Regress Rights.

\begin{abstract}
Abstrak-Di dalam masyarakat saat ini cek sebagai suatu surat berharga menjadi suatu yang lazim digunakan dalam transaksi perdagangan sebagai alat pembayaran yang praktis, dapat dialihkan dari suatu tangan ke tangan yang lain, sehingga dapat menunjang kelancaran perdagangan. Cek sebagai perintah tidak bersyarat dari pemegang rekening atau nasabah giro kepada bank untuk membayar sejumlah uang tertentu. Namun demikian yang menjadi masalah adalah pada saat diajukan kepada bank ternyata dana nasabah pada bank tidak mencukupi untuk membayar surat cek yang bersangkutan atau sering disebut sebagai cek kosong. Dalam penelitian ini penulis mengangkat permasalahan bagaimanakah tanggung jawab penerbit cek terkait dengan pembayaran dengan menggunakan cek kosong dan bagaimanakah perlindungan hukum terhadap penerima cek ketika menerima pembayaran dengan cek kosong. Tipe penelitian yang digunakan dalam penelitian ini adalah penelitian hukum normatif. Hasil dari penelitian ini adalah di dalam KUHD, cek kosong penarik atau seseorang yang atas tanggungannya cek itu ditarik, wajib berusaha agar dana yang diperlukan untuk pembayaran pada hari pengajuannya ada di tangan tertarik, sekalipun bila cek itu ditetapkan harus dibayar pihak ketiga, dengan tidak mengurangi kewajiban penarik sesuai dengan pasal. Perlindungan hukum terhadap penerima cek kosong adalah jaminan hukum berupa hak regres dalam hal tidak ada pembayaran hak regres baru akan timbul bila pemegang surat cek tidak mendapat pembayaran dari tersangkut setelah diminta pembayaran dalam 70 hari semenjak tanggal penerbitannya.
\end{abstract}

Kata kunci: Cek Kosong, Perlindungan Hukum, Hak Regres.

\section{Pendahuluan}

Di dalam masyarakat saat ini cek sebagai suatu surat berharga menjadi suatu yang lazim digunakan dalam transaksi perdagangan. Orangorang sekarang sudah banyak mengenal cek sebagai alat pembayaran kredit dan alat pembayaran kontan setelah uang selain sebagai alat pembayaran cek sangat praktis dan efisien. Dengan demikian cek adalah merupakan salah satu alat pembayaran selain mata uang. 
Di samping cek dikenal sebagai alat pembayaran yang praktis, cek dapat dialihkan dari suatu tangan ke tangan yang lain, sehingga masyarakat akan terkait menggunakan cek dan dapat menunjang kelancaran proses perdagangan. Selain hal tersebut di atas, cek juga mempunyai kegunaan yang lain, dimana cek dapat mengurangi resiko terhadap kejahatan misalnya perampokan dan penculikan. Mengingat peranan cek sangat besar dan sangat banyak keuntungannya dalam lalu lintas perdagangan dimana cek adalah sebagai salah satu pembayaran selain uang dan cek merupakan alat pembayaran yang praktis dan efisien sehingga orang-orang sudah banyak mengenal cek.

Sejarah cek berasal dari bahasa latin Chegue yang artinya meminjamkan, diartikan demikian karena pada saat itu para pedagang yang semula menggunakan sistem barter, selanjutnya diberikan pinjaman berupa selembar kertas yang berisikan kesanggupan untuk dapat dibayarkan kepada pihak lain sesama pedagang (Muhammad, 1991). Setiap orang pada umumnya dapat atau berhak menolak pembayaran yang dilakukan dengan cek, apabila orang ini tidak percaya pada orang yang mengeluarkan cek itu. Dari kedua definisi tersebut di atas pada dasarnya tidak ada perbedaan, sehingga cek digolongkan sebagai uang tunai walaupun belum diturunkan di bank dengan uang tunai.

Pada dasarnya pembayaran atau pemberian cek adalah suatu perbuatan hukum perdata. Pembayaran menggunakan cek biasanya digunakan untuk memudahkan penerbit dan memberikan keamanan karena tidak menyimpan uang dalam jumlah yang besar. Dalam praktik dimasyarakat seringkali penerima cek kosong, langsung menganggap pihak pemberi telah melakukan penipuan sehingga ia melaporkannya ke pihak berwajib sebagai suatu tindak pidana, padahal tindak semua pemberian cek kosong itu dapat dikategorikan sebagai perbuatan pidana, sehingga upaya keperdataan adalah merupakan suatu jalan yang lebih dahulu ditempuh sebelum penerima cek kosong tersebut menyimpulkan suatu tindak pidana.

Dengan penerbitan cek kosong tentu dapat memberikan kerugian kepada pihak pemegang cek kosong tersebut, padahal pemegang cek mendapatkan cek kosong tersebut dengan itikad yang baik oleh karena itu pemegang cek kosong wajib mendapatkan perlindungan hukum. Perlindungan hukum ini dimaksudkan agar pemegang mendapatkan kepastian hukum untuk memperoleh haknya kembali yakni berupa pembayaran atau pelaksanaan prestasi dari penerbit.

Berdasarkan latar belakang di atas, maka peneliti bertujuan menganalisis bagaimanakah tanggung jawab penerbit cek terkait dengan pembayaran dengan menggunakan cek kosong dan perlindungan hukum terhadap penerima cek ketika menerima pembayaran dengan cek kosong

\section{Metode}

Tipe penelitian yang digunakan adalah hukum normatif oleh karenanya pengkajiannya dilakukan melalui studi kepustakaan (library research) dengan pendekatan perundangundangan (statute approach), yaitu menganalisis permasalahan yang akan dibahas melalui konsep-konsep hukum yang diambil dari buku-buku dan literatur-literatur yang ada relevansinya dengan permasalahan.

\section{Hasil dan Pembahasan}

\section{Tanggung Jawab Penerbit Cek Terkait Pembayaran Cek Kosong}

Pokok pangkal terbitnya surat cek adalah perikatan dasar yang terjadi antara penerbit dengan pemegang pertama. Dalam hubungan ini penerbit berposisi sebagai debitur dan penerima sebagai kreditur. Untuk melakukan pembayaran debitur menerbitkan cek dan memerintahkan pihak ketiga yaitu tersangkut untuk membayar kepada penerima surat cek.

Tanggung jawab pihak lain terutama pihak terkait seperti pihak tersangkutan dan pihak Bank Indonesia dengan memberikan surat peringatan (somasi) sampai pada surat peringatan ketiga, apabila dalam surat peringatan ketiga pihak bank tersangkut mengirimnkan laporan ke Bank Indonesia untuk di black list dan untuk selanjutnya pihak penerbit cek tidak bisa lagi untuk melakukan penerbitan cek. Sedangkan sisa cek yang belum terpakai sepenuhnya diserahkan ke bank tersangkut atau pihak tersangkut akan meminta untuk mengembalikan cek tersebut.

Penarikan surat cek dari peredarannya hanya dapat dilakukan setelah berakhirnya jangka waktu penawaran. Dari ketentuan pasal ini dapat diketahui bahwa dalam jangka 70 hari. Sejak tanggal penerbitan surat cek dapat dibayar setiap saat diperlihatkan dan selama 70 hari itu pula surat cek tidak dapat ditarik kembali dari peredarannya. Penarikan kembali atau pembatalan surat cek mempunyai kekuatan 
hukum apabila penarikan atau pembatalan tersebut baru dilakukan selelah lampau 70 hari. Pencabutan atau penarikan kembali suatu cek adalah: "Penarikan kembali perintah membayar dari penerbit kepada tersangkut".

Hak regres pada surat cek dikenal bila terjadi non pembayaran, karena adakalanya tersangkut menolak pembayaran surat cek walaupun penawaran tepat pada waktunya. Pemegang yang menghadapi penolakan pembayaran itu merasa dalam keadaan tidak pasti mengenai hendaknya atas pembayaran dari tagihan yang tercantum dalam surat cek. Untuk mencegah dalam hal tersebut pembentuk undang-undang mengadakan peraturan yang memberikan hak pada pemegang untuk menuntut kepada orang lain juga bertanggung jawab atas pembayaran hutang cek. Hak yang diberikan ini disebut dengan hak regres. Dengan demikian hak regres baru akan timbul bila pemegang surat cek tidak mendapat pembayaran dari tersangkut setelah diminta pembayaran dalam jangka waktu yang tepat yaitu 70 hari semenjak tanggal penerbitannya.

Bila tidak terjadi pembayaran selama tenggang waktu tersebut pemegang dapat menuntut pembayaran terhadap debitur cek yang wajib seperti endosemen, avalis dan penerbit. Hak regres adalah : "Suatu hak menuntut dari pemegang terhadap perhutangpenghutang cek lainnya yang wajib regres (penghutang regre)" (Simanjuntak, 1982).

Mengenai pelaksanaan dari pada hak regres diatur diatur dalam Pasal 217 KUHD yang menyatakan : "Si pembawa cek dapat melaksanakan hak regresnya atas endosemenendosemen, si penarik dan orang-orang berhutang lainnya. Karena jangka waktu penawaran surat cek cukup lama, maka pemegang dapat meminta pembayaran kedua kalinya apabila yang kedua ini juga ditolak pemegang dapat lagi meminta pembayaran untuk yang ketiga kalinya dan seterusnya sampai tenggang wraktu 70 hari. Jika permintaan pada hari terakhir dari jangka waktu tersebut maka protes non pembayaran atau keterangan yang sama dengan itu dapat dibuat pada hari kerja berikutnya. Akan tetapi apabila proses pembayaran atau keterangan yang sama dengan itu telah dibuat tidak tepat pada waktunya maka penerbit tetap bertanggung jawab kecuali ia dapat membuktikan bahwa pada waktu surat cek diperlihatkan pada tersangkut dan untuk pembayaran sudah tersedia pada tersangkut. Menurut Pasal pemegang meregres endosannya. kemudia endosan ini meregres pula endosannya dan seterusnya sampai pada penerbit surat cek.
Mengenai pelaksanaan hak regres dapat dilakukan terhadap debitur yang wajib regers dapat dilakukan terhadap debitur yang wajib regres seperti endosemen, penerbit dan avalis. Cara pelaksanaannya dapat dilakuan secara rembours dan melompat (spiriogres). Secara melompat artinya pemegang surat cek dapat langsung meregres penerbit tanpa memperlihatkan urutan waktu (Pasal 221 KUHD) (Sumitro, 1994).

\section{Bentuk Perlindungan Hukum Terhadap Penerima Cek Kosong}

Dari ketentuan pasal surat-surat atas tunjuk atau atas pengganti yang jatuh ketangan orang dengan cara yang jujur, maka pemegang yang jujur ini dapat dituntut untuk mengembalikannya selama jangka waktu 3 tahun tersebut.

"Perlindungan terhadap pihak ketiga yang jujur sebagai satu kepastian adanya jaminan terlaksananya tujuan dan fungsi surat berharga yaitu untuk dapat diperdagangkan. Dengan pasti dapatlah kita katakan bahwa orang yang memperoleh sepucuk surat wesel, cek atau surat sanggup yang hilang atau berasal dari pencurian orang lain akan mendapat perlindungan, asal saja ia di dalam memperolehnya itu tidak beritikad jahat atau dapat dipersalahkan berat kepadanya" (Simanjuntak, 1982).

Perlindungan yang diberikan hukum terhadap pemegang cek yang beritikad baik juga diatur dalam pasal yang menyatakan :

"Bagi pemegang sehelai cek yang kemudian ternyata berasal dari pemegang terakhir yang menyerahkan cek itu bukan pemegang yang sah, karena diperolehnya dari penemuan di jalan, maka pemegang dari cek itu tidak diharuskan untuk mengembalikannya/ atau melepaskannya kecuali jika cek itu diperolehnya dengan itikad buruk atau karena suatu keteledoran yang besar".

Sehingga pemegang atau penerima cek haruslah berhati-hati dalam menyimpan cek sebelum diuangkan ke bank penerbit, agar jangan sampai hilang atau jatuh dijalan yang disebabkan karena keteledorannya sendiri, karena selama dia memperoleh cek itu dengan itikad baik dan tidak melakukan perbuatan melawan hukum maka penerima atau pemegang cek tersebut juga dilindungi berdasarkan pasal tersebut.

Dari definisi tersebut di atas, dapat dikatakan bahwa nasabah dari suatu bank hanya menerbitkan surat cek yang jumlah dananya 
maksimal sama dengan saldo giro yang ada dan ternyata bahwa pada waktu pembayaran penerbit tidak dapat menyediakan dana yang cukup kepada bank maka penerbit dikatakan menerbitkan cek kosong. Namun di dalam praktek ada beberapa orang yang berpendapat : "bahwa merupakan cek kosong jika cek tersebut telah dituangkan di bank dan ternyata kosong atau tidak mempunyai dana yang cukup" (Hamzah, 1979).

Akibat begitu tingginya ancaman hukuman yang dikenakan kepada penerima sesuai dengan pasal 1 dan juga terhadap penerbit sebagaimana diatur dalam pasal 2, dimana perbuatan tersebut dikategorikan sebagai suatu kejahatan, maka pelaku bisnis saat itu takut menggunakan alat pembayaran cek, sehingga UU tentang Cek Kosong tersebut dianggap menghambat perkembangan bisnis.

Kalau kita cermati ada beberapa masalah yang menyebabkan sehingga terbitnya surat cek kosong yaitu (Emirzon, 2002):

a. Kelemahan pasal yang berhubungan dengan penerbitan surat cek dan penyediaan dana pada bankir. Menurut ketentuan pasal, setiap surat cek harus diterbitkan atas seorang bankir yang mempunyai dana dibawah pengawasannya guna kepentingan penerbit, dana mana menurut perjanjian, tegas atau diam-diam, penerbit berhak menggunakannya dengan menerbitkan surat cek. Dalam pada itu, apabila ketentuan tersebut tidak diindahkan, atas hak itupun selaku surat cek tetap berlaku juga. Kelemahan pasal ini terletak pada kalimat kedua "apabila ketentuan-ketentuan di atas tidak diindahkan, surat cek yang diterbitkan itu tetap berlaku juga, hal ini berarti jika penerbit tidak menyediakan dana yang cukup pada waktu surat cek jatuh tempo, maka surat cek tersebut tetap sah. Pada dasarnya isi ketentuan pasal 180 KUHD bertujuan untuk melindungi pemegang surat cek yang jujur, oleh karena itu, si pemegang surat cek masih mempunyai hak atas surat cek dan dapat meminta pembayaran dengan menggunakan hak protes kepada penerbit.

b. Adanya rahasia bank seperti yang diatur dalam. Rahasia bank merupakan suatu yang wajib dipegang oleh pihak bank, oleh karena itu siapapun tidak akan tahu tentang keadaan keuangan seorang nasabah, seperti penerbit cek. Demikian juga si pemegang surat cek, yang penting waktu surat cek diunjukkan dana untuk surat cek cukup, karena penyediaan dana merupakan kewajiban dan tanggung jawab si penerbit, sadar atau tidak sadar si penerbit bertanggung jawab atas penyediaan dan tersebut. Dengan adanya kerahasiaan bank ini masyarakat akan percaya pada bank bahwa jumlah nasabah yang ada pada bank tidak diketahui oleh orang lain dan bank harus menjaminnya. Pengecualian terhadap hal tersebut di atas diatur dalam Pasal yang menyatakan Menteri Keuangan berwenang untuk memerintahkan kepada bank secara bertulis supaya memberikan keterangan dan memperlihatkan buku-buku, bukti-bukti tertulis atau surat-surat dan seorang nasabah untuk keperluan perpajakan. Juga menteri keuangan dapat memberikan ijin kepada jaksa atau hakim untuk meminta keterangan pada bank tentang keadaan keuangan tersangka demi kepentingan peradilan adlam perkara pidana. Speklualasi dari pihak penerbit:

c. Ada unsur spekulasi dari pemilik rekening firo, yaitu penerbit surat cek. Kadangkadang si penerbit dalam menerbitkan surat cek bersifat spekulasi, dengan harapan pada waktu jatuh tempo si penerbit dapat menyediakan dana yang cukup pada waktu jatuh tempo. Tindakan spekulasi ini kadang dimanfaatkan oleh para spekulan dalam lalu lintas pembayaran dengan surat cek, dalam arti, apabila surat cek itu baru diperlihatkan menjelang waktu peredarannya berakhir, maka si penerbit memiliki cukup waktu untuk mengusahakan dana guna membayar surat cek tersebut.

d. Administrasi bank yang kurang waspada, karena tidak menjalankan prinsip kehatihatian. Hal ini terjadi karena adanya sikap kurang waspada, misalnya ada pegawai bank yang bertindak tidak perlu memeriksa dana setiap surat cek yang diterbitkan, apakah dana untuk pembayaran surat cek tersebut cukup atau tidak? Sehingga dapat terjadi surat cek kosong yang diterbitkan oleh spekulan, tanpa kesulitan apapun.

Hak regres akan timbul apabila terjadi penolakan pembayaran dari tersangkut walaupun penawaran terjadi tepat waktunya. Pemegang yang menghadapi penolakan pembayaran itu, setidak-tidaknya berada atau merasa dalam keadaan yang tidak pasti mengenai haknya atas pembayaran dari tagihan yang tercantum dalam surat cek itu. Untuk melindungi pemegang cek yang mengalami penolakan pembayaran dari tersangkut, termasuk karena tida ada dananya (kosong), maka kepada pemegang diberikan wewenang untuk menuntut orang lain yang juga bertanggung jawab atas pembayaran cek itu, 
yaitu hak regres. Suatu hak untuk menuntut dari pemegang terhadap penghutang-penghutang cek lainnya yang berwajib regres (penghutang regres) (Simanjuntak, 1982).

Di dalam KUHD hak regres diatur pada Bab 6 Hak Regres dalam hal non pembayaran.

Hak regres diberikan kepada pemegang jika telah memenuhi beberapa syarat yang antara lain :

a. Cek harus diajukan pada waktu yang tepat, yakni sebelum lampaunya tenggang waktu pengajuan. Hal ini disebabkan karena cek tidak memiliki hari bayar. Cek dibayarkan setiap saat ditunjukkan. Karena pada dasarnya pembayaran dengan cek adalah pembayaran secara tunai.

b. Tidak ada pembayaran

c. Penolakan itu dianggap sah bila memenuhi ketentuan undang-undang yaitu :

- Ada protes dimana protes dibuktikan secara tertulis (otentik)

- Adanya pernyataan dari tersangkut yang ditanda tangani dan ditulis di halaman muka cek dengan mencantumkan hari pengajuannya.

- Dengan suatu keterangan yang ditanda tangani dan ditanggali oleh Balai Pemberesan, yang menyatakan bahwa cek sudah diajukan pada waktu yang tepat dan tidak ada pembayaran.

Didalam pasal ini juga diatur mengenai tenggang waktu pembuatan protes atau pernyataan yang sama yang menentukan bahwa protes atau pernyataan yang sama dengan itu harus dibuat sebelum akhir tenggang penawaran. Tenggang wakti itu juga harus diperhatikan, bila pemberitahuan itu melalui kantor pos, sebab dilanggarnya ketentuan masalah tenggang waktu ini dapat mengakibatkan hilangnya hak untuk regres.

Dalam pelaksanaannya hak regres itu dapat dilakukan dengan dua cara yaitu :

a. Rembours artinya pemegang regres endosannya dan seterusnya sampai pada penerbit surat cek

b. Spring regres (melompat) artinya pemegang cek dapat langsung meregres penerbit tanpa memperhatikan urutan waktu sebagaimana diatur

Sebagai bentuk perlindungan hukum terhadap penerima cek, hak regres dapat berisi tuntutan antara lain :

a. Jumlah surat cek yang tidak dibayar

b. Bunga 6 (enam) \% terhitung mulai hari pengunjukannya

c. Biaya protes atau pernyataan yang sama dengan itu, biaya segala pemberitahuan yang telah dilakukan dan biaya lain-lain.

Berbeda halnya dengan pemegang surat cek atas tunjuk tidak dapat meregres pemegang sebelumnya, karena tidak dapat diketahui selama tidak ada tanda tangannya pada cek itu, sehingga tidak dikenai wajib regres, akan tetapi jika endosan itu menaruh tanda tangannya pada cek itu, maka ia terikat juga sebagai debitur wajib regres.

Suatu hal yang sangat penting dalam penerbitan cek itu adalah pembayarannya sebab dengan dilaksanakannya pemenuhan kewajiban pembayaran atas cek oleh tertarik, telah pula menghapuskan perhutangan/ perikatan yang ada antara si Penarik dengan si pemegang cek itu. Berdasarkan ketentuan pasal, setiap cek harus dibayar pada waktu diperlihatkan. Surat cek yang diperlihatkan untuk pembayarannya sebelum hari yang disebut sebagai hari tanggal diterbitkan surat cek itupun harus dibayar pada hari diperlihatkan (Muhammad, 1991). Surat cek semacam ini biasa disebut surat cek bertanggal mundur (post dated cheque).

Pembayaran cek tak lepas dari kewajiban penerbit sebagai pemilik rekening giro untuk menyediakan dana untuk membayar cek yang diterbitkannya, jika dananya cukup maka surat cek harus dibayar seluruhnya, namun jika dana yang dimiliki ternyata belum mencukupi, maka penerbit diminta supaya mencukupkan dana yang dimilikinya pada rekening giro. Akan tetapi jika dana direkening giro ternyat tidak ada sama sekali, maka tersangkut akan menolak pembayaran surat cek itu. Dalam hal tersangkut melakukan penolakan surat cek berdasarkan alasan saldo tidak cukup untuk dilakukan kliring, tersangkut wajib menatausahakan penarikan cek kosong pemilik rekening giro serta mengembalikan surat cek tersebut kepada pemegang atau penerima cek. Berdasarkan peraturan, yaitu dalam hal Cek dan/atau Bilyet Giro ditolak dengan alasan (Tanya Jawab Peraturan Bank Indonesia No. 18/43/PBI/2016 tentang Perubahan atas Peraturan Bank Indonesia Nomor 8/29/PBI/2006 tentang Daftar Hitam Nasional Penarik Cek dan/atau Bilyet Giro Kosong):

Cek kosong juga terjadi apabila apabila 
penerbit sudah dikategorikan black list oleh pihak Bank Indonesia karena pihak penerbit cek sudah berulang kali melakukan pembayaran dengan menggunakan cek yang dananya kurang atau sama sekali tidak ada dana, maka pihak bank tersangkut mengadakan penolakan dan telah melakukan somasi sebanyak tiga kali berturut-turut, sehingga pihak bank bersangkut mengirim data black list ke Bank Indonesia agar tidak melakukan transaksi pembayaran dengan menggunakan cek.

Black list atau daftar hitam adalah suatu daftar yang berisi nama-nama penarik cek kosong yang diterbitkan oleh Bank Indonesia dan berlaku selama 1 (satu) tahun sejak tanggal penerbitannya. Dikeluarkannya daftar hitam nasional ini dimaksudkan untuk mencegah penarikan cek dan/atau bilyet giro kosong dalam rangka memelihara dan meningkatkan kepercayaan masyarakat dalam penggunaan Cek dan/atau Bilyet Giro sebagai instrumen pembayaran.

\section{Simpulan}

Dari uraian hasil pembahasan di atas maka penulis dapat membuat beberapa kesimpulan yaitu Tanggung jawab penerbit terkait dengan pembayaran dengan menggunakan cek kosong adalah pihak penerbit mengadakan negosiasi kepada penerima cek kosong untuk memenuhi sejumlah nilai yang tertuang di dalam cek kosong dengan mengadakan pembayaran tunai dan menarik cek kosong yang telah diterima oleh penerima cek kosong mengganti dengan cek yang aru dengan sejumlah nilai uang yang tertera dan dana yang tersedia didalam cek memadai, melakukan penundaan pembayaran oleh penerbit cek dengan penerima cek.

Perlindungan hukum terhadap pemegang cek ketika penerima pembayaran dengan cek kosong, pihak penerima cek kosong dapat menuntut ganti kerugian lewat pengadilan dengan acara perdata, cek tidak dapat diminta oleh penerbit cek apabila belum mencapai waktu 70 hari dapat mengadakan negosiasi kepada penerbit cek untuk memenuhi kewajibannya senilai yang tertera dalam cek. dan apabila dalam waktu yang telah ditemukan undang-undang pihak penerbit dapat di black list di Bank Indonesia.

\section{Daftar Pustaka}

Emirzon, J. (2002). Hukum Surat Berharga dan Perkembangannya di Indonesia. Jakarta: Prenhallindo.
Muhammad, A. (1991). Hukum Surat-Surat Berharga suatu Pengantar. Bandung: Alumni.

Simanjuntak, E. P. (1982). Hukum Dagang Surat-surat Berharga, Seksi Hukum Dagang. Yogyakarta.

Sumitro, R. T. (1994). Kitab Undang-Undang Hukum Dagang dan Undang-Undang Kepailitan. Pradnya Paramita.

Tanya Jawab Peraturan Bank Indonesia No. 18/43/PBI/2016 tentang Perubahan atas Peraturan Bank Indonesia Nomor 8/29/ PBI/2006 tentang Daftar Hitam Nasional Penarik Cek dan/atau Bilyet Giro Kosong.

Hamzah, A. (1979). Hukum Pidana Ekonomi. Jakarta: Erlangga. 